\title{
Correspondance
}

\section{Words of truth}

W ho is this writer called Dr. Ursus? I have been stopped in my tracks by the "Query" essays now appearing in CMAF's prime location (the last page, which is, of course, the first page) and am compelled to read in entirety his words of truth.

The "stupid family doctor" essay ${ }^{1}$ of early February is now on the list of mandatory reading for final-year family medicine residents rotating through our clinic. This cogent one-pager restores some of the self-esteem and confidence bleached out of family physicians by tertiary care institutions. And his more recent remarks about applying evidence-based medicine to day-to-day general practice ${ }^{2}$ remind us that real patients have agendas of their own, most often quite different from the physician's. One must first acknowledge and respond to the patient's needs - otherwise, unrecognized, they are pretty well guaranteed to hijack the best intentions of the evidence-based practitioner.

Let us hear more from Dr. Ursus.

\section{Bob Heyes}

Family Doctor (and proud of it)

Haliburton, Ont.

\section{References \\ 1. CMA7 2004;170(3):432. \\ 2. CMAF 2004;170(5):912.}

DOI:10.1053/cmaj.1040406

I could not agree more with Dr. Ursus about the tragic situation he describes in the Feb. 3 issue of $C M A 7 .{ }^{1}$ $\mathrm{He}$ is perfectly correct in saying that " $[\mathrm{t}]$ he single greatest change in the firmament of modern Canadian medicine will remain the death of the generalist."

Of course, the reasons for this "death" are many, but, in my opinion, they rank in the following order. First, the loss of the rotating internship has unfortunately resulted in the exposure of virtually none of our graduating medical students to the joy of general practice. Second, because medical schools are now being administered and the teaching is being done by specialists and subspecialists, students get a view of the practice of medicine that is totally different from that of the generalist. Third, general practitioners have disappeared from major teaching hospitals, so there are no role models in this area, an aspect of training that I think is extremely important for the typical medical student in 2004.

Dr. Ursus suggests that physicians were better served by the rotating internship, and I can only commiserate with him on this point. Family doctors indeed are a dying breed, and I suspect that 10 to 15 years from now there will be none left.

\section{Noel Barry Hershfield \\ Gastroenterologist \\ Calgary, Alta.}

\section{Reference}

1. CMAF 2004;170(3):432.

DOI:10.1053/cmaj.1040455

I agree with Dr. Ursus that it sometimes seems difficult to balance the rights of patients to top-notch care and the need to provide a superior education for the next generation of physicians. ${ }^{1}$ More to the point, however, is the issue of the core philosophy applied in educating our future physicians. Many faculties of medicine have introduced the patient-centred approach as a core educational concept in their undergraduate and postgraduate curricula. In a commentary last year, I described the evolution of emergency medicine teaching and practice in Canada. ${ }^{2}$ Dr. Ursus now offers me an additional opportunity to weigh in on the need to refocus our attention on the patient as a whole person, in contrast to the viewing of a child as "the broken arm in cubicle 5." On reading Dr. Ursus's description of his family's experience in the emergency department, ${ }^{1}$ I was shocked but not surprised that his child was sent for radiography without any analgesia. To learn, teach and serve as a role model for empathy and caring are skills just as important as mastering the arts of diagnosis and treatment. With time, I hope we will see more attending physicians, residents and medical students who understand that the urgent alleviation of suffering is one of our highest duties. My learners know that triaging and starting appropriate resuscitation go hand in hand with making the patient comfortable. This approach, in addition to being humane, provides for a less stressful, and less potentially litigious, encounter for all. It also facilitates better compliance on the part of the patient and the family and improves patients' satisfaction and their perception of the quality of the care received.

I commend Dr. Ursus for his resolution to treat families more gently. I hope many more will follow his path.

Ivan P. Steiner

Department of Family Medicine and

Division of Emergency Medicine

University of Alberta

Edmonton, Alta.

\section{References}

1. CMA7 2004;170(7):1192.

2. Steiner IP. Emergency medicine practice and training in Canada [editorial]. CMAf 2003;168 (12):1549-50.

DOI:10.1053/cmaj.1040627

\section{Food fights: common good versus individual interests}

T $\mathrm{t}$ is likely that the "food fights" dis1 cussed in a recent CMAJ editorial will easily be won by the food industrialists. Given that their political lobbies obfuscate government messages on healthy eating ${ }^{2}$ and stop government agencies from advising people to eat less, ${ }^{3}$ it can reasonably be predicted that those lobbies will also successfully undermine the attempts of the World Health Organization (WHO) to improve diet, ${ }^{4}$ especially when US congressmen "recruited by the food industry" have urged the secretary of health to cut off that country's US\$406-million annual contribution to the WHO. ${ }^{4}$

The CMAf editorial ${ }^{1}$ appropriately 
mentioned the "detailed list of quibbles" put forward by the US Department of Health and Human Services, ${ }^{5}$ questioning the scientific basis of the new WHO strategy on diet and physical activity. ${ }^{6}$ As Dyer ${ }^{4}$ has pointed out, "[w]henever you hear the government or the industry talking about scientific rigour . . . it's code for self interest." Food fights, therefore, constitute an unequal struggle between the common good, represented axiomatically by public health, and the individual interests of food manufacturers, who are so powerful as to influence and shape government policies. ${ }^{2-4}$

Morality, in its original meaning, ${ }^{7}$ suggests that the individual interests of food industrialists should no longer be privileged over the innumerable human lives that could be saved by preventing obesity and its tragic consequences. ${ }^{8}$ Strict regulations on food production and its advertising are urgently needed worldwide and should be respected by market forces. Otherwise, to contain increasingly catastrophic epidemics of nutrition-related disorders, many governments will probably be compelled to turn food companies into nationalized, nonprofit organizations.

\section{Riccardo Baschetti}

Medical Inspector (retired)

Fortaleza, Brazil

\section{References}

1. Food fights [editorial]. CMAf 2004;170(5):757.

2. Marwick C. Food industry obfuscates healthy eating message. BM7 2003;327:121.

3. Elliot A. US food industry ensures that consumers are not told to eat less. BMF 2003;327:1067.

4. Dyer O. US government rejects WHO's attempts to improve diet. BM7 2004;328:185.

5. Integrated prevention of noncommunicable diseases. Draft global strategy on diet, physical activity and health [doc no EB113/44 Add.1]. Geneva: World Health Organization; 2003 Nov 27. Available: www.who.int/gb/EB_WHA/PDF /EB113/eeb11344a1.pdf (accessed 2004 Apr 7).

6. US Departments of Health and Human Services and Agriculture. Review of Diet, Nutrition and the Prevention of Chronic Diseases. Rockville (MD): US Department of Health and Human Services, Office of Global Health Affairs; 2003 Jan 2. Available: http://cspinet.org/new/pdf /steigerltr.pdf (accessed 2004 Apr 7).

7. Baschetti R. Ethical analysis in public health [letter]. Lancet 2002;360:416.

8. Mokdad AH, Marks JS, Stroup DF, Gerberding JL. Actual causes of death in the United States, 2000. 7AMA 2004;291:1238-45.

Competing interests: None declared.

DOI:10.1053/cmaj.1040495

\section{Medical privacy is important}

$\mathrm{A}$ s noted in a recent "News@ a Glance" item, ${ }^{1}$ the use and abuse of oxycodone is a growing concern in Canada, particularly in Nova Scotia. ${ }^{2}$ The lay press has reported that police and pharmacists in that province would like a province-wide database to be established to track users of narcotic medications prescribed for pain relief, especially drugs containing oxycodone; ${ }^{3}$ it is believed that such a database would help to prevent "double-doctoring."

Drug databases can certainly be used by primary care physicians to improve the quality of patient care and to ensure that patients are not exposed to dangerous drug interactions. ${ }^{4}$ However, it is important that patients' privacy be protected. If patients think that the police may have access to such a database, those suffering from legitimate chronic pain may be less likely to seek appropriate medical care.

Before consideration is given to violating patients' privacy, a good first step would be a study to determine the effectiveness of such a database in detecting double-doctoring. The seriousness of the problem of drug addiction does not justify the unethical violation of medical privacy, even when it is done with the best of intentions.

\section{Andrei S.P. Brennan}

Research Ethics Quality Assurance

Officer

Research Institute of the McGill

University Health Centre

Montréal, Que.

\section{J.A. Chris Delaney}

Statistician

Division of Clinical Epidemiology

Royal Victoria Hospital

Montréal, Que.

\section{References}

1. Sibbald B. OxyContin task force. CMA7 2004; 170(3):326.

2. Moulton D. "Hillbilly heroin" arrives in Cape Breton. CMA7 2003;168(9):1172.

3. Canadian Press. Pharmacists call for prescription database. In: CTV.ca [Web site]. [place unknown]: Bell Globemedia; 2004 Mar 8. Available: www.ctv.ca/servlet/ArticleNews/story /CTVNews/1078677993092_38?hub=Health (accessed 2004 Apr 11).

4. Tamblyn R, Huang A, Perreault R, Jacques A, Roy D, Hanley J, et al. The medical office of the 21st century (MOXXI): effectiveness of computerized decision-making support in reducing inappropriate prescribing in primary care. $C M A \mathcal{F}$ 2003;169(6):549-56.

Competing interests: None declared.

DOI:10.1053/cmaj.1040446

\section{Genetics and ARMD}

Thank you for Erica Weir's Public Health article on age-related macular degeneration (ARMD). ${ }^{1}$ The term for this condition sounds like an apology for our inability to identify a better cause, but in fact genetics plays a large role in a person's predisposition to macular degeneration. Several genes may be associated with macular degeneration, including $A B C A 4, V M D 2$, EFEMP1, TIMP3, ${ }^{2}$ ELOVL4 ${ }^{3}$ and $C R X .^{4}$ However, a search for mutations in these genes in patients with a diagnosis of ARMD has been disappointing, except in the case of $A B C A 4$. Patients who carry mutations in both $A B C A 4$ alleles have an autosomal recessive disorder called Stargardt disease. ${ }^{5}$ Allikmets $^{6}$ has shown a significantly higher incidence of mutations in the $A B C A 4$ gene among patients with ARMD than in a control population. These mutations may contribute to the higher risk of vision loss from ARMD among first-degree relatives of patients with the condition, estimated at 4 times the risk for the general population. ${ }^{7}$

How can ARMD be prevented? As mentioned by Weir, stopping smoking and eating a healthy diet are both important. In particular, eating fish at least twice a week reduces the risk. ${ }^{8}$ Fish is an excellent source of omega-3 fatty acids, in particular docosahexaenoic acid, the predominant highly unsaturated fatty acid of the retina. With people now living into their 80 s, a healthy lifestyle and a healthy diet are important not only for general wellbeing but also for good vision.

\section{Ian M. MacDonald}

Matthew A. Lines

Ocular Genetics Laboratory

University of Alberta

Edmonton, Alta. 